MATEC Web of Conferences 15, 01034 (2014)

DOI: $10.1051 /$ matecconf/ 20141501034

(C) Owned by the authors, published by EDP Sciences, 2014

\title{
The Mechanical Properties of Foamed Concrete containing Un-processed Blast Furnace Slag
}

\author{
H. Awang ${ }^{1}$, Z. S. Aljoumaily ${ }^{2}$, N. Noordin ${ }^{3}$, M. Z. Al-Mulali ${ }^{4}$ \\ ${ }^{1,2,3,4}$ School of Housing, Building \& Planning, Universiti Sains Malaysia, P. Pinang 1800, Malaysia
}

\begin{abstract}
For many years, supplementary cementation materials have been utilized as cement or filler replacements to heighten the properties of concrete. The objective of this paper is to demonstrate the effects of un-processed blast furnace slag (RS) on the compressive, splitting tensile and flexural strengths of foam concrete over periods of 7, 14 and 28 days. The introduction of slag to the cement begins at $30 \%$ and rises to $70 \%$ of the total content. Six mixes, which include the control mix with a similar mix ratio (1:2:0.45) and a dry density of $1300 \mathrm{~kg} / \mathrm{m}^{3}$ is generated. Taking into consideration, from the total weight of the cementation material, $1 \%$ of super- plasticizer (PS-1) is added to the mixes with slag content. Test results revealed that the most favourable (optimum) replacement level of un-processed slag in foam concrete is $30 \%$. This represents a commercial advantage as the cement requirement is reduced from $414 \mathrm{Kg} / \mathrm{m}^{3}$ to $290 \mathrm{Kg} / \mathrm{m}^{3}$. On the $28^{\text {th }}$ day, the optimum mix showed higher values than the control mix by $32 \%$ for compressive strength, $46.5 \%$ for splitting tensile strength and $61 \%$ for flexural strength.
\end{abstract}

\section{Introduction}

For over six decades, foam concrete, also known as cellular concrete, has been widely used in the construction industry [1]. Dijik [2] describes foam concrete as a slurry or mortar based substance containing a minimum of $20 \%$ (by volume) mechanically entrained foam in a plastic material. The foam concrete densities vary $\left(300 \mathrm{Kg} / \mathrm{m}^{3}\right.$ to $\left.1800 \mathrm{Kg} / \mathrm{m}^{3}\right)$ according to the amount of calculated stabile foam added to the mortar in order to attain the required density. Compared to other techniques, the pre-foamed method was found to be more economical and easy to manage. The production of foam concrete is considered environmentally friendly as it consumes a minimum amount of natural resources and the resulting by-products (fly ash, blast furnace slag, rice husk ash etc.) can be used as cement and filler replacements $[3,4,5]$.

Slag from blast furnaces is a by-product from the melting of iron ore, limestone and coke at a temperature of $1500 \mathrm{C}^{\circ}$. Molten slag, which floats on the molten iron, is made up mostly of silicates, alumina and some oxides. Currently, factories lower the temperature of slag through the projection of pressurized water or exposure to air in large fields with the usage of a small amount of water. Rapid cooling of molten slag hinders the creation of large crystals and results in the formation of a granular material containing $95 \%$ non-crystalline calcium-aluminosilicates. With a maximum particle size of $5 \mathrm{~mm}$, slag is comparable to sand. It ranges from dark beige to off-white in colour depending on the moisture content [6],[7].

Maier and Durham [8] studied the effects of introducing recycled material into regular concrete at varying levels of replacement beginning from $25 \%$ and rising to $75 \%$. When the introduction of 
Ground Granulated Blast-furnace Slag (GGBS) was increased, he detected a reduction in unit weight. The highest strength recorded in his study was when the level of slag replacement arrived at $50 \%$ $\left(5240 \mathrm{~cm}^{2} / \mathrm{gr}\right)$ of the cement content. On the $28^{\text {th }}$ day the strength value recorded in his study was higher than the control mix by about $18.6 \%$ for $50 \%$ replacement, and lower than the control mix by about $5 \%$ for both $25 \%$ and $75 \%$ replacements. This phenomenon, which was also noted by Bijen [9], can be attributed to the fact that the slag is mostly under the control of $\mathrm{C}_{2} \mathrm{~S}$ rather than $\mathrm{C}_{3} \mathrm{~S}$. The research work by Topçu and Boga [10] regarding the effects of GGBS (4230 $\left.\mathrm{mm}^{2} / \mathrm{gr}\right)$ on reinforced concrete had a maximum cement content of $300 \mathrm{Kg} / \mathrm{m}^{3}$. His study involved the use of $25 \%-50 \%$ of GGBS as cement replacement with air and water as curing regimes. A reduction in unit weight was noted with the introduction of GGBS. At the replacement level of $25 \%$, the recorded compressive strength was the highest for both regimes. While the splitting tensile strength in the water curing regime exhibited a noteworthy rise for the mix content with $25 \%$ GGBS, a decline was apparent for the air curing regime. Babu and Kumar [11] scrutinized the efficiency of the mixes from $10 \%$ to $80 \%$ $\left(3500 \mathrm{~mm}^{2} / \mathrm{gr}-4650 \mathrm{~mm}^{2} / \mathrm{gr}\right)$ of regular concrete substitution by GGBS and observed greater strength on the $28^{\text {th }}$ day with a replacement of $30 \%$ GGBS. A maximum dosage $(2 \%)$ of Super- Plasticizer was used for the cementation material. Memon et al. [12] conducted a study using three mix ratios (1:2, $1: 2.5$ and 1:3) in a mortar based mixture. By substituting 50\% of the cement content with GGBS and utilizing a super-plasticizer $0.5 \%$, she achieved increased material strength in 28 days and a reduction in unit weight that was in tandem with an increase in slag content. However, Aydin [13], observed a decline in mortar compressive strength when the level of GGBS $\left(4850 \mathrm{~mm}^{2} / \mathrm{gr}\right)$ was elevated at a temperature of $20 \mathrm{C}^{\mathrm{o}}$. Generally, these results concur with the findings of Dehuai and Zhaoyuan [14]. His study involved the use of ternary blended cement comprising slag and fly ash in varying ratios in a mortar base.

In order to generate lightweight aerated concrete, Aguilar et al. [15], used blast furnace slag (BF) $(85 \%$ retained in sieve $420 \mu \mathrm{m})$ as fine aggregate. $75 \%$ metakaolin was utilized as the binder with $25 \%$ fly ash as $100 \%$ substitute for PC. The mix ratio for all mixes was set at 1:1 (binder: filler) with distinct densities $\left(600 \mathrm{Kg} / \mathrm{m}^{3}, 900 \mathrm{Kg} / \mathrm{m}^{3}\right.$ and $\left.1200 \mathrm{Kg} / \mathrm{m}^{3}\right)$ and temperatures $\left(20^{\circ}\right.$ and $\left.75^{\circ}\right)$ for the curing regimes. He noted that by using $100 \% \mathrm{BF}$ as fine aggregate with a density of $1200 \mathrm{~kg} / \mathrm{m}^{3}$, close to the same strength can be attained in a normal curing temperature of $20^{\circ}$. With regard to flexure strength, a higher level of strength was observed with the inclusion of BF and an increase in the curing temperature. Wee et al. [16] produced Grade 20 lightweight foam concrete in 28 days with a wet density $1310 \mathrm{Kg} / \mathrm{m}^{3}$. To achieve this they used blended cement (50\% GGBFS) with a fixed water/binder ratio (0.3) and excluded fine aggregate. Aljoumaily et al. [17] conducted studies to investigate the effects of non-grinded slag on the compressive strength of foam concrete. As for this research, $40 \%$ of non-grinded slag was used as a replacement for cement and $1.5 \%$ super-plasticizer was used for the cementation material. The dry density, binder/filler ratio and water/binder ratio were determined as $1300 \mathrm{Kg} / \mathrm{m}^{3}, 1: 2$ and 0.45 respectively. As part of a research in progress, this paper will delve into the use of un-processed slag as a cement replacement (30\%-70\%) and identify its effects on the mechanical properties of foam concrete (compressive, flexure, and splitting tensile strengths) for the periods of 7, 14 and 28 days.

\section{Materials and Methods}

\subsection{Materials}

Presented below are the materials utilized for this study, which measure up to international standard requirements. Cement: The cement selected for this study goes by the trade name 'Blue Lion' and is manufactured by Cement Industries of Malaysia Berhad (CIMA Group). It has been categorized as type 1 cement by BSEN 196-1; 2005 [18] and meets the specifications set by ASTM C150 [19] and Malaysian Standard MS 522: part I (1). The chemical composition of the cement is exhibited in Table 1. 
Table 1: Chemical composition of OPC

\begin{tabular}{cc}
\hline Constituent & Chemical Composition W\% \\
\hline Lime $(\mathrm{CaO})$ & 65.3 \\
Silica $\left(\mathrm{SiO}_{2}\right)$ & 21.09 \\
Alumina $\left(\mathrm{Al}_{2} \mathrm{O}_{3}\right)$ & 5.46 \\
Iron oxide $\left(\mathrm{Fe}_{2} \mathrm{O}_{3}\right)$ & 3.5 \\
Magnesia $(\mathrm{MgO})$ & 2.06 \\
Sulphur trioxide $\left(\mathrm{SO}_{3}\right)$ & 2.14 \\
$\mathrm{~N}_{2} \mathrm{O}$ & 0.05 \\
Loss of ignition & 0.64 \\
Lime saturation factor & 0.92 \\
$\mathrm{C}_{3} \mathrm{~S}$ & 52.82 \\
$\mathrm{C}_{2} \mathrm{~S}$ & 21.45 \\
$\mathrm{C}_{3} \mathrm{~A}$ & 9.16 \\
$\mathrm{C}_{4} \mathrm{AF}$ & 10.2 \\
\hline
\end{tabular}

Sand: The fine aggregate conformed to the specifications of BS 812-103.1:1985 [20] for verifying distribution and particle size. Unprocessed Slag (RS): The blast furnace slag utilized for this study was obtained from a Malaysian steel factory. It has a particle size of between $0.15 \mathrm{~mm}$ and $1.18 \mathrm{~mm}$. Replacement began at the level of $30 \%$ and rose by $10 \%$ each time until the level of $70 \%$. The unprocessed slag used for this study conformed to the conditions set by BS EN 15167-1:2006 [21] and its chemical composition is listed in Table 2.

Table 2: Chemical composition of unprocessed slag (RS)

\begin{tabular}{cc}
\hline Components & Chemical Composition W\% \\
\hline $\mathrm{SiO}_{2}$ & 38 \\
$\mathrm{CaO}$ & 39 \\
$\mathrm{Al}_{2} \mathrm{O}_{3}$ & 12 \\
$\mathrm{MgO}$ & 8.5 \\
$\mathrm{MnO}$ & 0.6 \\
$\mathrm{TiO}_{2}$ & 0.6 \\
$\mathrm{~S}$ & 0.5 \\
$\mathrm{TFe}$ & 0.4 \\
\hline
\end{tabular}

Foaming Agent and Machinery: A black, protein based foaming agent (NORAITE PA-1) with a water dilution ratio of 1:30 was utilized to generate stabile foam with a density of between $62 \mathrm{Kg} / \mathrm{m}^{3}-$ $68 \mathrm{Kg} / \mathrm{m}^{3}$. DRN Concrete Resources, a Malaysian company, produced the foam generating machine (PM-1) and the foaming agent (PA-1).

Super-Plasticizer (PS-1): Taking the weight of the binder into consideration, 1\% of super-plasticizer is added to the mixes with slag replacement content. The foaming agent and additives should be tested in advance for compatibility in order to eliminate any negative effects on the properties of foam concrete [22]. A broad perspective on PS-1 made available by the supplier is shown in Table 3 .

Table 3: General Information on PS-1

\begin{tabular}{cc}
\hline General Information & PS-1 \\
\hline Chemical content & $\begin{array}{c}\text { A mixture of sodium acids and } \\
\text { glycol compounds based on Sulphonates }\end{array}$ \\
\hline Appearance & Brown to light brown coloured liquid \\
\hline Rate of dosage (by the weight of the binder $\%)$ & $0.2 \%-2 \%$ \\
\hline
\end{tabular}




\section{a. Mixing Procedures}

For this study, seven mixes were generated according to a consistent mix ratio of 1:2:0.45 with a constant dry density of $1300 \mathrm{Kg} / \mathrm{m}^{3}$ and a variation of $150 \mathrm{Kg} / \mathrm{m}^{3}$. Each constituent is weighed prior to mixing based on the wet density. Table 4 displays the constituents of the seven mixes. The additives were tested by adding them to the control mix to detect any effects on the mechanical properties with and without the presence of RS. First to go into the mixer (which should be wet) is sand and 10\% of the calculated water. After a thorough mixing, the cementation material was added together with the remaining water. The additive was included gradually until the mortar attained workability (flow table test). Mixing was allowed to progress until a uniform mixture was achieved and $20 \mathrm{~cm}-23 \mathrm{~cm}$ for the mortar flow table test was attained for all mixes. The density of the mixture was measured by first weighing a one-litre cup filled with the mix. The foam weight was then determined through calculations of the actual mortar volume and the total volume. The rate of foam inclusion is dependent on the flow rate of the machine (litre/ sec). Periodic stalling may be necessary in order to allow the foam and mortar to mix thoroughly. A tolerance on plastic density was set at $\pm 50 \mathrm{~kg} / \mathrm{m}^{3}$ of the wet density value, which is the standard practice in the foamed concrete production industry [17],[23],[24].

Table 4: Constituent Kg. per cubic meter

\begin{tabular}{cccccc}
\hline Mix & $\begin{array}{c}\text { Cement } \\
{[\mathbf{K g}]}\end{array}$ & $\begin{array}{c}\text { Sand } \\
{[\mathbf{K g}]}\end{array}$ & $\begin{array}{c}\text { Water } \\
{[\mathbf{K g}]}\end{array}$ & $\begin{array}{c}\text { RS } \\
{[\mathbf{K g}]}\end{array}$ & $\begin{array}{c}\text { PS-1 } \\
{[\mathbf{K g}]}\end{array}$ \\
\hline CF & 414.6 & 828.3 & 186.4 & - & - \\
CFP & 414.6 & 828.3 & 186.4 & - & 4.14 \\
SF-30 & 290.2 & 828.3 & 186.4 & 124.4 & 4.14 \\
SF-40 & 248.8 & 828.3 & 186.4 & 165.8 & 4.14 \\
SF-50 & 207.3 & 828.3 & 186.4 & 207.3 & 4.14 \\
SF-60 & 165.8 & 828.3 & 186.4 & 248.7 & 4.14 \\
SF-70 & 124.4 & 828.3 & 186.4 & 290.2 & 4.14 \\
\hline
\end{tabular}

Steel moulds with varying dimensions were used to hold the resultant mix. The measurements of the moulds are as follows: compressive strength - 100x100x100mm, flexural strength 500x100x100mm and splitting tensile strength $-200 \mathrm{~mm}$ in height $\times 100 \mathrm{~mm}$ in diameter (cylinder shaped). After 24 hours the samples were removed from the moulds and wrapped in polythene film for curing before testing.

\section{Results and Discussions}

A Twenty four hours prior to testing, the specimens were exposed to an oven temperature of $105 \mathrm{C}^{\circ} \pm 2 \mathrm{C}^{\mathrm{o}}$ for drying. Following this, an average reading of the three samples was taken for each period (7, 14 and 28 days). ELE International, with a capacity for $2000 \mathrm{KN}$, a paste rate of $2.5 \mathrm{KN} / \mathrm{s}$ for compression, $0.94 \mathrm{KN} / \mathrm{s}$ for splitting and $0.2 \mathrm{KN} / \mathrm{s}$ for flexure was the machine used for testing. Graphs were generated to represent the results procured from the tests. The three specimens were investigated for each situation and the average values calculated. The following is a discussion on the results obtained from the tests.

\subsection{Fresh and Hardened Densities}

For the purpose of approximating the volumetric value of the foam, the mortar was weighed during the mixing process. The plastic density level is inclined to rise in tandem with an increase in the percentage of slag, while a reduction in plastic density reduces the presence of foam (Figure 1). For this study the variation between dry and wet density was depicted as $150 \mathrm{Kg} / \mathrm{m}^{3}$. The density loss for the period prior to the day of testing (before oven drying), and on the day of testing (after oven 
drying) was an average of three cubes. As displayed in Figure 2, it is apparent that except for CF-70, all the mixes experienced a tolerable loss in density throughout. The substantial loss in density experienced by CF-70, which surpassed the acceptable level, can be attributed to the high level of slag content. The hydration process and pozzolanic reaction led to a higher loss in average density during the early phase. However, this loss rate declined during the later phases. These results concur with those of TopçU and Boga [10], Memon et al. [12].

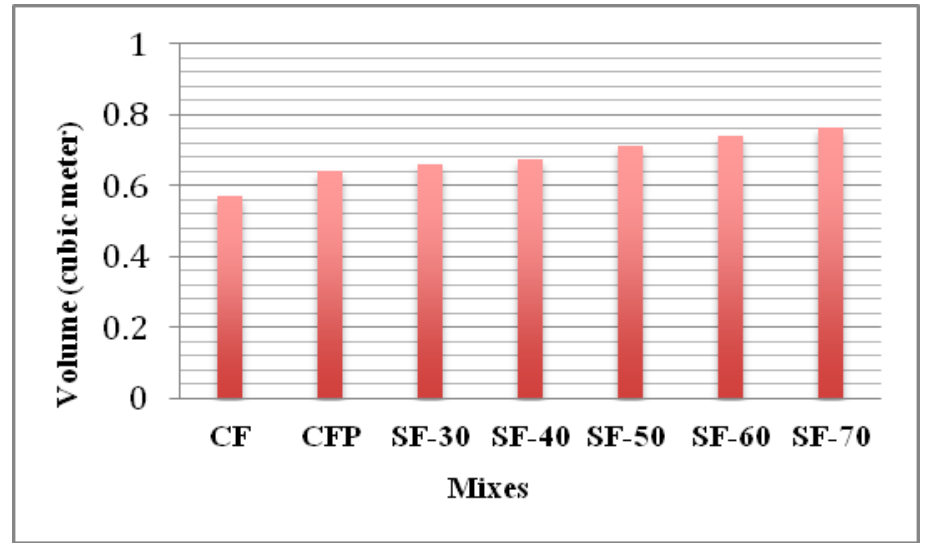

Figure 1: Mortar volume related to replacement level

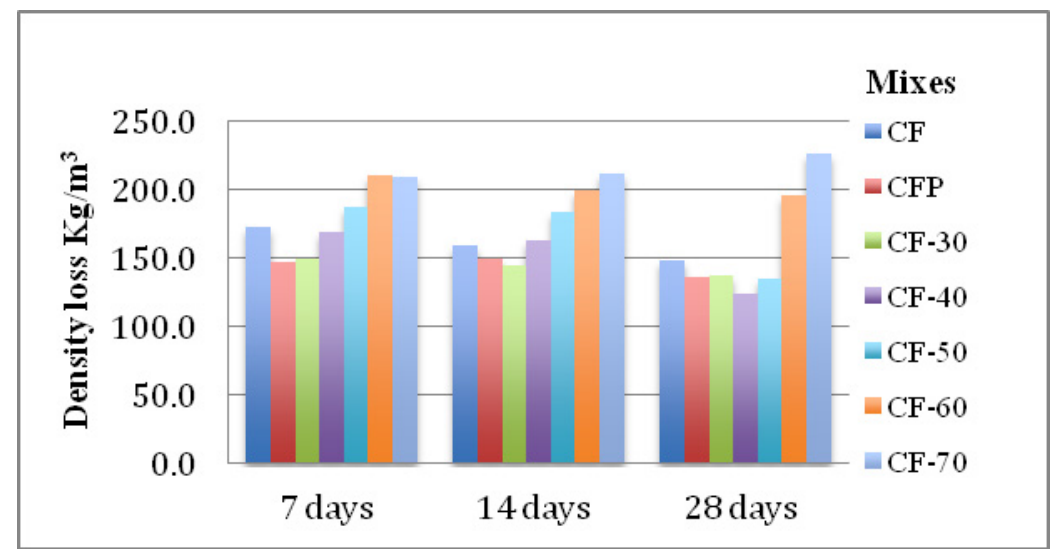

Figure 2: Density loss during the periods of 7, 14 and 28 days.

With regard to density loss, the results reveal similar behaviour for the mixes CFP and CF-30 comparing with other mixes. This shows that the volumetric value and distribution of the Air-void system are close to identical for both mixes with each having a substantial disparity in cement content.

\subsection{Compressive Strength}

Tests which were conducted in compliance with BS EN 12390-3:2009 [26] revealed that in general, the seven mixes achieved higher levels of strength in 28 days. For the most part, earlier studies were more concerned about using GGBS as a material as fine as, or finer than cement. For this study, the assessment will focus on strength development with regard to cement replacement by unprocessed slag. From Figure 3, it is apparent that the CFP mix attained a higher level of strength for the periods of 7, 14 and 28 days ( $98.4 \%$ above that of the control mix) compared to the other mixes. The objective of this mixing was to observe the effects of the additive (PS-1) and its compatibility 
with the foaming agent with regard to strength enhancement. The control mix (CF) gained strength $(5.01 \mathrm{MPa})$ during the 28 day period and this result is almost similar to those obtained by Hamidah et al. [27] and Jones and McCarthy [25]. Newman and Owens [28] discussed the general properties of lightweight concrete and stated that after 28 days the average strength of foam concrete with a density ranging from $1200 \mathrm{Kg} / \mathrm{m}^{3}$ to $1400 \mathrm{Kg} / \mathrm{m}^{3}$ was $4.5 \mathrm{MPa}$ to $8 \mathrm{MPa}$. Generally, the mixes CF-30, CF-40 and CF-50, which contain a 30\% to $50 \%$ replacement level of unprocessed slag attained strength superior to that of the CF mix by approximately $32 \%, 20.5 \%$ and $7.6 \%$ respectively. British Standard $15167-1,2006$ [21] considers $50 \%$ to be the ideal replacement level of cement by GGBS. However, this level can be raised to accommodate specific objectives. Relevant literature is mostly of the opinion that utilizing GGBS with varied fineness and a replacement level of up to $50 \%$ results in increased strength. Results from the first three levels of replacements in this paper $(30 \%, 40 \%$ and $50 \%$ ) are in agreement to those in studies conducted by Maier and Durham [8], Babu and Kumar [11], Memon et al. [12] and Aljoumaily et al. [17]. The mixes CF-60 and CF-70 progressed throughout the periods $(7,14$, and 28 days) and increased in strength by $74.9 \%$ and $50.3 \%$ respectively from the control mix.

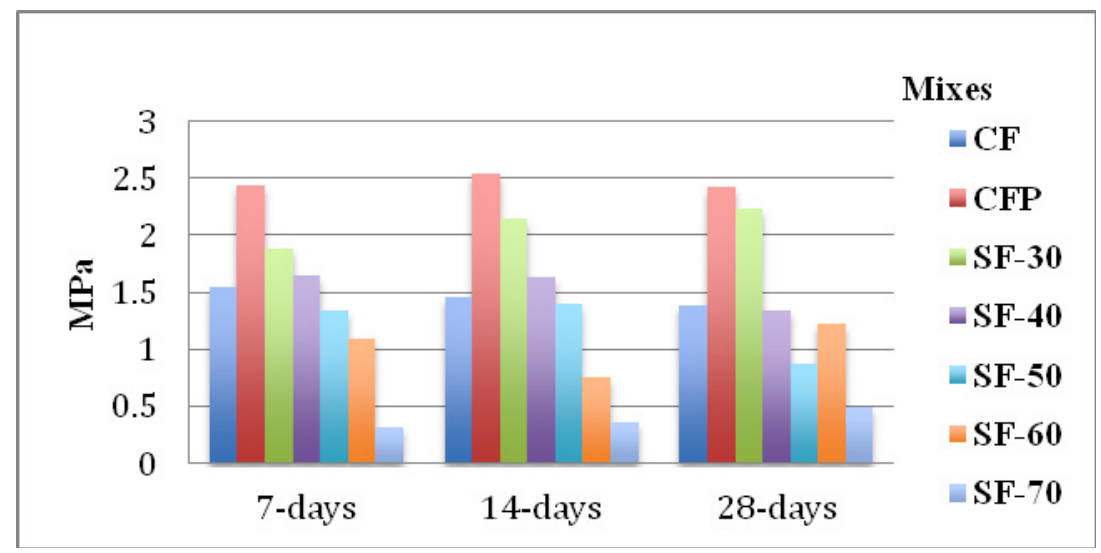

Figure 3: Compressive Strength through different periods

\subsection{Flexure Strength}

With an average from three samples and in compliance with BS 12390-5: 2009, the flexural test (four points bending test) was conducted on all seven mixes at 7, 14 and 28 days (Figure 4). The results reveal that the highest flexural strength recorded on the $28^{\text {th }}$ day was $2.4 \mathrm{MPa}$ for the CFP mix.

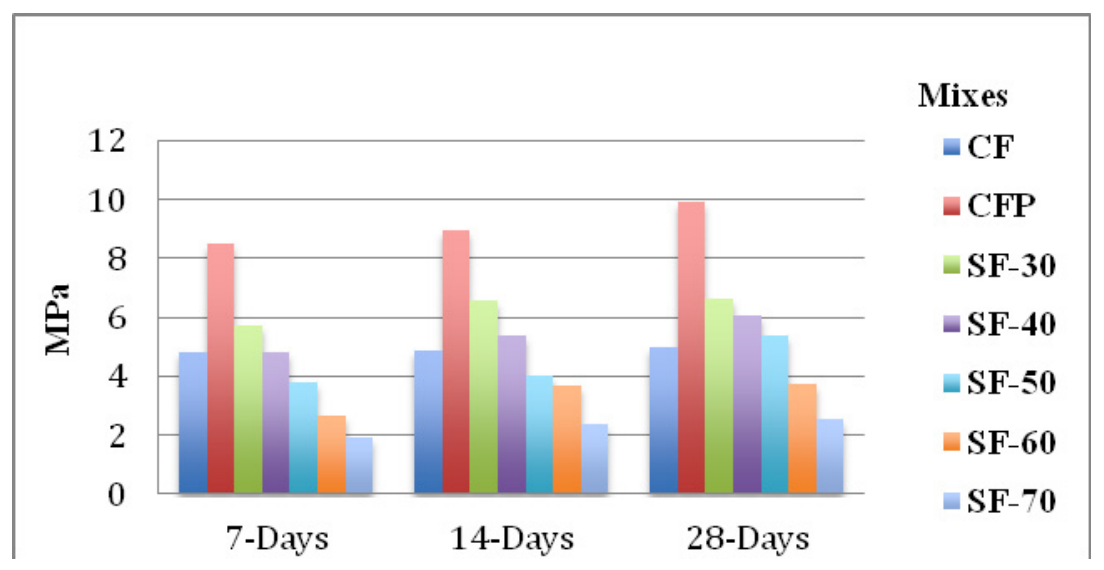

Figure 4: Flexure strength through different periods 
The CF mix attained a flexural strength of $1.4 \mathrm{MPa}$ in 28 days. This result is similar to that obtained by Awang et al. [29]. The SF-30 mix recorded an impressive flexural strength that was $61 \%$ greater than that of the CF mix with a cement content of less than $300 \mathrm{Kg} / \mathrm{m}^{3}$. It is clear that when the replacement level is beyond $30 \%$, a decline in flexural strength transpires. The mixes SF-40, SF-50, SF-60 and SF-70 attained flexural strengths of $96 \%, 63 \%, 87.9 \%$ and $36 \%$ respectively from the control mix. The outstanding flexure to compressive strength ratio of 0.34 was achieved by the SF-30 mix. Researchers conducted in the past produced similar results within a range of 0.25 to 0.35 [5]. The remaining mixes generated ratios of 0.16 to 0.27 which are higher than those achieved in research conducted by Jones and McCarthy [25].

\subsection{Splitting Tensile Strength}

Testing on the splitting tensile strength was carried out with an average from three samples and in accordance with BS EN 12390-6:2009 [30]. The results derived from testing the seven mixes through the three periods of 7,14 and 28 days are exhibited in Figure 5. These results clearly follow a similar trend to the results obtained through flexural testing. However, the mix with a replacement level of $0 \%$ and with PS-1 (CFP) developed through the periods and attained a strength level that was $63 \%$ greater than that of the control. On the $28^{\text {th }}$ day the control mix (CF) registered a gain of $0.694 \mathrm{MPa}$ and a tensile/compressive ratio that was almost similar to that obtained in a test carried out by Jones and McCarthy [25]. The mixes with 30\% (SF-30) and 40\% (SF-40) slag replacement attained a greater strength level than the control by approximately $46.5 \%$ and $2.9 \%$ respectively. On the other hand, SF50, SF-60 and SF-70 achieved strength levels that were lower than the control mix by $28 \%, 33 \%$ and $63.7 \%$ respectively. The highest tensile/ compressive ratio was achieved by SF-30 (0.153) which is close to those realized in tests conducted by Ramamurthy et al. [5] and Jones and McCarthy [25].

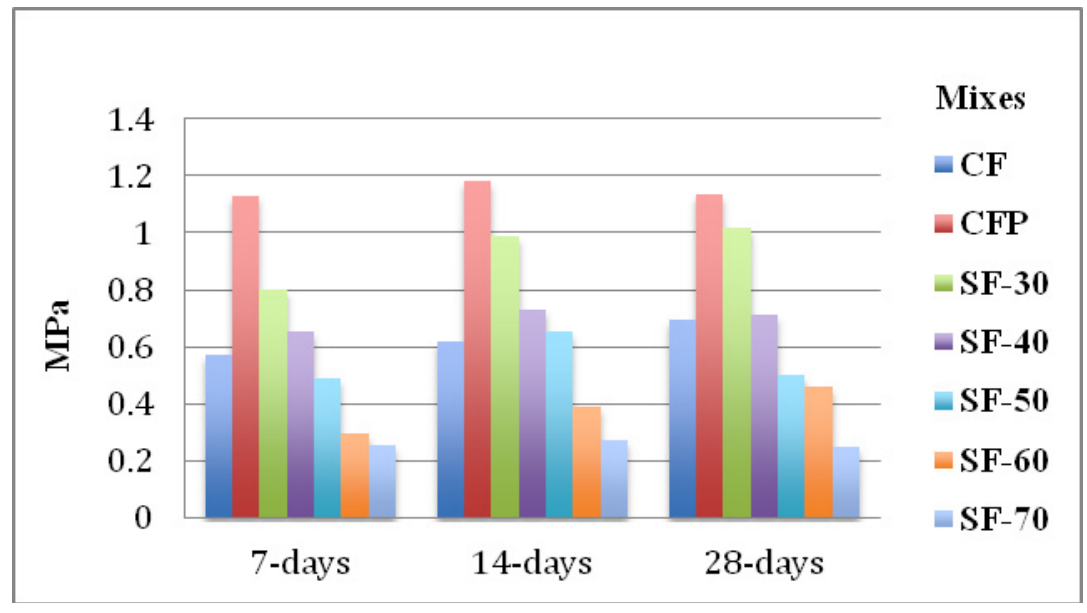

Figure 5: Splitting tensile strength through different periods

\section{Conclusions}

Based on the test results of this study, the following can be surmised.

- The usage of slag will not only reduce the cost of foam concrete but also enhance its level of resilience. Cement content can be reduced by slag replacement and maintained at below 300 $\mathrm{Kg} / \mathrm{m}^{3}$.

- Instead of fine slag, which requires more energy and effort to produce, the use of unprocessed blast furnace slag as a cement replacement appears promising. With a 
replacement level of $30 \%$ up to $50 \%$ and a mix ratio of $1: 2: 0.45$, the compressive strength achieved was greater than that of the control mix.

- At 30\% and 40\% of cement replacement by unprocessed slag (30\% and $40 \%)$, flexural and splitting tensile testing produced better results than the $\mathrm{CF}$.

- The results derived from testing the seven mixes indicate that the optimum replacement level is $30 \%$ of unprocessed slag in foam concrete with a mix ratio of 1:2:0.45 (cement content $<300 \mathrm{Kg}$ and superior mechanical properties compared to the control mix).

\section{Acknowledgement}

We would like to thank Mr. Lim Hong Hock, Mr. Yoong Wai and Mr. Ng Beng Fooi of Ann Joo Resources Berhad for providing me with the materials required for this research. Your generous contributions are greatly appreciated.

\section{References}

1. Ulhaq, M. \& Alex, L.(2007).Light Weight/Low Cost Construction Methods For Developing Countries. International workshop- cement based material and civil infrastructure (CBM-CI) Karachi, Pakistan, 491-504.

2. Dijik, S. V. (1991). Foamed concrete in Concrete, UK. Slough : British Cement Association. pp. 49-54

3. Kearsley, E. P.(1996). The use of foamcrete for affordable development in third world countries 232-242.

4. Noordin, N. \& Awang, H. (2005).Lightweight Foamed Concrete in Construction.International Conference on Construction and Real Estate Management,The Challenge of Innovation. Building Press.,Penang, Malaysia.

5. Ramamurthy, K.,Nambiar, E. K. K. \& Ranjani, G. I. S. (2009). A classification of studies on properties of foam concrete. Cement and Concrete Composites, 31(6), 388-396

6. AïTcin, P. C. (2008). Binders for Durable and Sustainable Concrete,London and New york. Taylor \& Francis pp.373-513

7. Siddique, R. \& Khan, M. I. (2011). Supplementary Cementing Materials, London New York. Springer. pp. 121-174

8. Maier, P. L. \& Durham, S. A. (2012). Beneficial use of recycled materials in concrete mixtures. Construction and Building Materials, 29, 428-437.

9. Bijen, J. (1996). Benefits of slag and fly ash. Construction and Building Materials,, 10(5), 309314.

10. TopçU, I. B. \& Boga, A. R. (2010). Effect of ground granulate blast-furnace slag on corrosion performance of steel embedded in concrete. Materials and Design, 31, 3358-3365.

11. Babu, K. G. \& Kumar, V. S. R. (2000). Efficiency of GGBS in concrete. Cement and Concrete Research 30, 10311036.

12. Memon, N. A.,Sumadi, S. R. \& Ramli, M. (2007). Performance of high wokability slag-cement mortar for ferrocement. Building and Environment, 42, 2710-2717.

13. Aydin, S. 2008. Development of a high-temperature-resistant mortar by using slag and pumice. Fire Safety Journal 43, 610-617.

14. Dehuai, W. \& Zhaoyuan, C. (1997). On predicting compressive strength of mortars with ternary blended cement, GGBFS and Fly ash Cement and Concrete Research,, 27(4), 487-493. 
15. Aguilar, R. A.,Díaz O. B. \& García J. I. E. (2010). Lightweight concretes of activated metakaolin-fly ash binders, with blast furnace slag aggregates. Construction and Building Materials, 24, 1166-1175.

16. Wee, T.-H., Babu, D. S.,Tamilselvan, T. \& Lim H.-S. (2006). Air-Void System of Foamed Concrete and its Effect on Mechanical Properties. ACI Material 103(1), 45-52.

17. Aljoumaily, Z. S. ,Noordin, N., Awang, H. \& Almulali, M. Z. (2012). The Effect of Blast Furnace Slag on Foam Concrete in Terms of Compressive Strength. Advanced Materials Research, 587,81-87.

18. BS EN 196-1:2005 (2005) .Methods of testing cement.Determination of strength. BSI,London, UK.

19. ASTM: C 150 Standard Specification for Portland Cement.ASTM international,USA.

20. BS 812-103.1:1985 (1985), Testing aggregates. Method for determination of particle size distribution. Sieve tests. BSI,London, UK.

21. BS EN 15167-1:2006, (2006). Ground granulated blast furnace slag for use in concrete, mortar and grout. Definitions, specifications and conformity criteria. BSI,London, UK.

22. American Concrete Institute (ACI) (2006). 523.1R-06 Guide for Cast-in-Place Low Density Cellular Concrete.

23. Mahmood, Z. S. \& Noordin, N. (2010). Low-Medium Cost House "Design And Construction Two Storey House From Lightweight Concrete". Master, Univesiti Sains Malaysia.

24. Jones, M. R. \& Mccarthy, A. (2005a). Preliminary views on the potential of foamed concrete as a structural material. ice, 57(1), 21-31.

25. Jones, M. R. \& Mccarthy, A. (2005b).Behaviour and assessment of foamed concrete for construction Applications University of Dundee, UK, 61 - 83.

26. BS EN 12390-3:2009.(2009), Testing hardened concrete.Compressive strength of test specimens. BSI.,London, UK.

27. Hamidah, M.,Azmi, I.,Ruslan, M.,Kartini, K. \& Fadhil, N.(2005).Optimisation of foamed concrete mix of different sand-cement ratio and curing conditions.(DHIR, R.K.,NEWLANDS, M.D.\&MCCARTHY, A.), Thomas Telford.,University of dundee, Scotland, UK., 37-50.

28. Newman, J. \& Owens P. (2003). Properties of lightweight concrete. In: JOHN NEWMAN, B.S.C. (ed.) Advanced Concrete Technology Processes. USA: Elsevier Ltd.

29. Awang, H.,Othuman, M. A. \& Roslan, A. F. (2012). Effect of additives on mechanical and thermal properties of lightweight foamed concrete Advances in Applied Science Research,, 3(5), 3326-3338.

30. BS EN 12390-6:2009,(2009) Testing hardened concrete.Tensile splitting strength of test specimens. BSI.,London, UK. 